\title{
Bioflocculant production from untreated corn stover using Cellulosimicrobium cellulans L804 isolate and its application to harvesting microalgae
}

\author{
Weijie Liu* (B), Chenchu Zhao, Jihong Jiang, Qian Lu, Yan Hao, Liang Wang and Cong Liu*
}

\begin{abstract}
Background: Microalgae are widely studied for biofuel production. Nevertheless, harvesting step of biomass is still a critical challenge. Bioflocculants have been applied in numerous applications including the low-cost harvest of microalgae. A major bottleneck for commercial application of bioflocculant is its high production cost. Lignocellulosic substrates are abundantly available. Hence, the hydrolyzates of rice stover and corn stover have been used as carbon source to produce the bioflocculant in previous studies. However, the hydrolyzates of biomass required the neutralization of $\mathrm{pH}$ before the downstream fermentation processes, and the toxic by-products produced during hydrolysis process inhibited the microbial activities in the subsequent fermentation processes and contaminated the bioflocculant product. Therefore, strains that can secrete plant cell-wall-degrading enzymes and simultaneously produce bioflocculants through directly degrading the lignocellulosic biomasses are of academic and practical interests.
\end{abstract}

Results: A lignocellulose-degrading strain Cellulosimicrobium cellulans L804 was isolated in this study, which can produce the bioflocculant MBF-L804 using untreated biomasses, such as corn stover, corn cob, potato residues, and peanut shell. The effects of culture conditions including initial pH, carbon source, and nitrogen source on MBF-L804 production were analyzed. The results showed that over $80 \%$ flocculating activity was achieved when the corn stover, corn cob, potato residues, and peanut shell were used as carbon sources and $4.75 \mathrm{~g} / \mathrm{L}$ of MBF-L804 was achieved under the optimized condition: $20 \mathrm{~g} / \mathrm{L}$ dry corn stover as carbon source, $3 \mathrm{~g} / \mathrm{L}$ yeast extract as nitrogen source, $\mathrm{pH}$ 8.2. The bioflocculant MBF-L804 contained $68.6 \%$ polysaccharides and $28.0 \%$ proteins. The Gel permeation chromatography analysis indicated that the approximate molecular weight (MW) of MBF-L804 was 229 kDa. The feasibility of harvesting microalgae Chlamydomonas reinhardtii and Chlorella minutissima using MBF-L804 was evaluated. The highest flocculating efficiencies for C. reinhardtii and C. minutissima were 99.04 and $93.83 \%$, respectively.

Conclusions: This study shows for the first time that C. cellulans L804 can directly convert corn stover, corn cob, potato residues and peanut shell into the bioflocculants, which can be used to effectively harvest microalgae.

Keywords: Bioflocculant, Cellulosimicrobium cellulans, Corn stover, Microalgae harvest, Biofuels

\section{Background}

In recent years, microalgae have received increasing attention for the production of biofuels and various valueadded products [1-5]. However, economic production

*Correspondence: leonliu2013@126.com; liucong0426@126.com School of Life Science, The Key Laboratory of Biotechnology for Medicinal Plant of Jiangsu Province, Jiangsu Normal University, No.101, Shanghai Road, Tongshan new District, Xuzhou 221116, Jiangsu, China of these products is hampered by high cost in harvesting and dewatering of biomass, which can account for $20-30 \%$ of total cost [3, 6-8]. Existing technologies used for harvesting microalgal cells include centrifugation, filtration, flotation, gravity sedimentation, and flocculation, either used individually or in combination $[1,2,6]$. Centrifugation can harvest more than $90 \%$ of the microalgae, but requires extra energy input [9-12]. Filtration is 
effective only for the large multicellular microalgae, and is not economical due to the low efficiency and the frequent filter replacement $[12,13]$. Coagulation/flocculation followed by gravity sedimentation or flotation is a relative inexpensive approach for microalgae harvest [14-19]. Co-cultivation of some fungal strains have been reported to be able to assist algal flocculation [6, 20,21], however, this method requires long culture time [3], and is not applicable for harvesting all microalgae.

Bioflocculants are extracellular polymeric substances including polysaccharides, proteins and nucleic acids secreted by microorganisms [22-24]. Bioflocculants are advantageous over inorganic flocculants and chemically synthetic flocculants in numerous applications including low-cost harvest of microalgae and wastewater treatment, due to their nontoxic, harmless, and biodegradable properties [3, 23, 25, 26]. The bioflocculants produced by Solibacillus silvestris W01 [3], Paenibacillus sp. AM49 [7, 16], and Burkholderia cepacia [27] have been applied in microalgae harvest. However, a major bottleneck for commercial application of these bioflocculants is the high production cost $[28,29]$. Current studies commonly focused on isolating high production strains, optimizing fermentation conditions and seeking for low-cost substrates [30-32]. Activity sludge was applied as raw material to produce bioflocculants [33-36], and various wastewaters were used as cheap carbon source to reduce the production cost, such as potato starch wastewater [37-39], palm oil mill effluent [40, 41], dairy wastewater [31], chromotropic acid wastewater [42], and brewery wastewater [43]. Agricultural wastes, such as rice stover and corn stover, are abundantly available and rich in lignocelluloses, hydrolyzates of which have been applied as carbon source to produce bioflocculants [29, 44]. However, the hydrolyzate of biomass requires the neutralization of $\mathrm{pH}$ before the downstream fermentation processes [29, 44, 45], and the hydrolyzates of biomass always contain toxic by-products, such as phenolic compounds and furan derivatives, which inhibit the microbial activities in the subsequent fermentation processes [46-48], and are difficult to remove from the bioflocculant product. In some cases, the algae or algal residues are used to produce other valuable products, such as proteins and carbohydrates [2]. Thus, the contamination of bioflocculants by these toxic by-products will limit their application. Therefore, strains that can secrete lignocellulolytic enzymes and simultaneously produce bioflocculants through directly degrading lignocellulosic biomasses are of academic and practical interests.

In this study, a lignocellulose-degrading strain Cellulosimicrobium cellulans L804, which can produce bioflocculant MBF-L804 through degrading lignocellulosic biomasses directly, was isolated from corn farmland soil.
Subsequently, the optimal fermentation conditions of strain L804 were investigated, and the feasibility of harvesting two microalage Chlamydomonas reinhardtii and Chlorella minutissima using MBF-L804 was evaluated. The results showed that $C$. cellulans L804 can convert untreated corn stover, corn cob, potato residues, and peanut shell into bioflocculants, which exhibited high flocculating activities in microalgae harvest. Therefore, this study provides a novel way to produce bioflocculant, and achieve the resourceful utilization of abundantly available lignocellulosic biomass, which can promote the industrial application of bioflocculant in microalgae harvest.

\section{Results and discussion}

\section{Isolation and identification of bioflocculant-producing} strains

Twelve cellulase-producing and xylanase-producing strains were isolated from corn farmland soil samples. Among them, one strain, named L804, was identified as a bioflocculant-producing strain with high flocculating activity. Strain L804 was Gram positive, rod shaped, and aerobic strain. The colony of L804 was circular and moist. The 16S rRNA of strain L804 was sequenced after PCR amplification and deposited into GenBank database (accession number: KT280277). A total of 1400 bp of $16 \mathrm{~S}$ rRNA was determined and compared with the sequences of the GenBank database. The highest level of $16 \mathrm{~S}$ rRNA sequence similarity to Cellulosimicrobium cellulans was $99 \%$. Therefore, strain L804 and its bioflocculant product were named C. cellulans L804 and MBF-L804, respectively. In previous studies, C. cellulans has been reported to produce an array of plant cell-wall-degrading enzymes, such as endo- $\beta$-1,3-glucanases, proteases, and mannanases [49]. C. cellulans has also been reported to secrete the lignocellulolytic enzymes, such as cellulase and xylanase, and thus has the capacity for degrading lignocellulosic biomass $[44,50,51]$. In this study, C. cellulans L804 was also found to be able to secrete cellulase and xylanase (Fig. 1). More importantly, it was observed for the first time that $C$. cellulans produces bioflocculant. Therefore, strain L804 has potential to produce bioflocculant by degrading the lignocellulosic biomass directly.

In previous studies, the hydrolyzates of some lignocellulosic biomasses, such as rice stover [44] and corn stover [29], were used as carbon source to produce the bioflocculants. However, these biomasses were hydrolyzed under high-temperature and strong acidic conditions $\left(121^{\circ} \mathrm{C}\right.$ and $1.7 \%$ sulfuric acid) $[29,44]$. After acidic hydrolysis, a neutralization of $\mathrm{pH}$ is necessary for the downstream fermentation processes [29, 44, 45], and the acidic hydrolysis process always produces toxic by-products, such as phenolic compounds, furan derivatives, and carboxylic acids, which are major fermentation inhibitors 

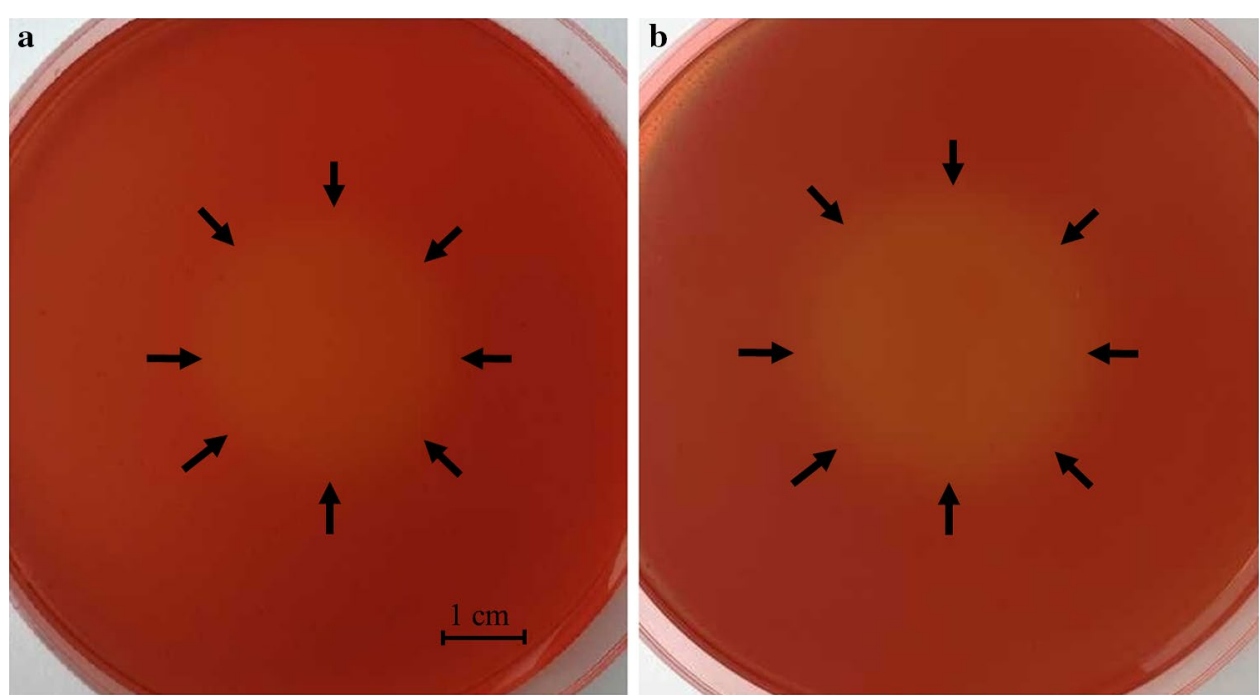

Fig. 1 Cellulase (a) and xylanase (b) of C. cellulans L804 analyzed using the medium containing CMC or Xylan. Images were taken at the culture time of $72 \mathrm{~h}$. The bar indicates $1 \mathrm{~cm}$

for the activities of bioflocculant-producing strain [52], and are difficult to remove in the extraction process, and thus contaminate the bioflocculant product. In this study, C. cellulans L804 was found to be able to utilize untreated lignocellulosic biomasses as carbon sources to produce bioflocculant, which can achieve the resourceful utilization of lignocellulosic biomass.

\section{MBF-L804 production in the medium with different initial $\mathrm{pH}$}

The initial $\mathrm{pH}$ of the medium was adjusted using $\mathrm{Na}_{2} \mathrm{CO}_{3}$ and $\mathrm{HCl}$ solution. The effects of $\mathrm{pH}$ variation in the range of 6.0-10.5 on the cell growth and MBF-L804 production were analyzed. As shown in Table 1, C. cellulans L804 produced bioflocculant MBF-L804 in the initial

\section{Table 1 Effects of initial $\mathrm{pH}$ on cell growth and flocculating activity}

\begin{tabular}{|c|c|c|c|}
\hline Initial pH & Final $\mathrm{pH}$ & Cell growth $\left(\mathrm{OD}_{600}\right) \mathrm{F}$ & $\begin{array}{l}\text { Flocculating } \\
\text { activity }^{\text {a }}(\%)\end{array}$ \\
\hline 6.0 & $7.78 \pm 0.15$ & $1.61 \pm 0.10$ & $3.82 \pm 0.36$ \\
\hline 6.9 & $8.03 \pm 0.14$ & $1.76 \pm 0.02$ & $61.27 \pm 4.81$ \\
\hline 7.4 & $8.52 \pm 0.16$ & $1.04 \pm 0.21$ & $88.15 \pm 4.55$ \\
\hline 8.2 & $9.07 \pm 0.03$ & $1.00 \pm 0.08$ & $90.88 \pm 4.87$ \\
\hline 9.2 & $9.14 \pm 0.06$ & $0.88 \pm 0.02$ & $88.30 \pm 4.41$ \\
\hline 9.8 & $9.23 \pm 0.02$ & $1.20 \pm 0.04$ & $83.73 \pm 2.56$ \\
\hline 10.2 & $9.21 \pm 0.02$ & $1.30 \pm 0.05$ & $54.50 \pm 0.71$ \\
\hline 10.5 & $10.18 \pm 0.10$ & $0.02 \pm 0.01$ & $31.95 \pm 6.49$ \\
\hline
\end{tabular}

\pm , indicates standard deviation of at least three replicates

${ }^{a}$ Flocculating activity was determined using Kaolin clay as solid phase
$\mathrm{pH}$ range of 7.4-9.8, and the final $\mathrm{pH}$ range was 8.5-9.2. Therefore, C. cellulans L804 is an alkali-resistant strain. Previous studies reported that weak alkaline treatment opens up the cell wall of lignocellulosic materials, leading to an increase in internal surface area, a decrease in the degree of polymerization, and a decrease in crystallinity; and the separation of structural linkages between lignin and carbohydrates [45]. Therefore, weak alkaline culture condition can improve the degradation efficiency of lignocellulosic biomass, and the highest flocculating activity of $90.88 \%$ was achieved at initial $\mathrm{pH} 8.2\left(\mathrm{Na}_{2} \mathrm{CO}_{3}\right.$ concentration was $0.4 \mathrm{~g} / \mathrm{L}$ ). Therefore, $0.4 \mathrm{~g} / \mathrm{L} \mathrm{Na}_{2} \mathrm{CO}_{3}$ was selected to adjust initial $\mathrm{pH}$ of the fermentation medium in the following experiments.

\section{Effects of nitrogen sources on MBF-L804 production}

The effects of nitrogen sources on MBF-L804 production were investigated. Figure $2 \mathrm{a}$ shows the effects of different nitrogen sources on MBF-L804 production. Among the nitrogen sources investigated, ammonium sulfate, sodium nitrate, and urea resulted in poor cell growth and flocculating activity. Comparatively, yeast extract, casein, trypepton, beef extract, and peptone were significantly better sources for MBF-L804 production. Yeast extract was selected as the optimal nitrogen source in the following experiments because it was favorable for the MBFL804 production.

\section{Effects of carbon sources on MBF-L804 production}

The effects of various carbon sources on MBF-L804 production were then studied when yeast extract was used as 


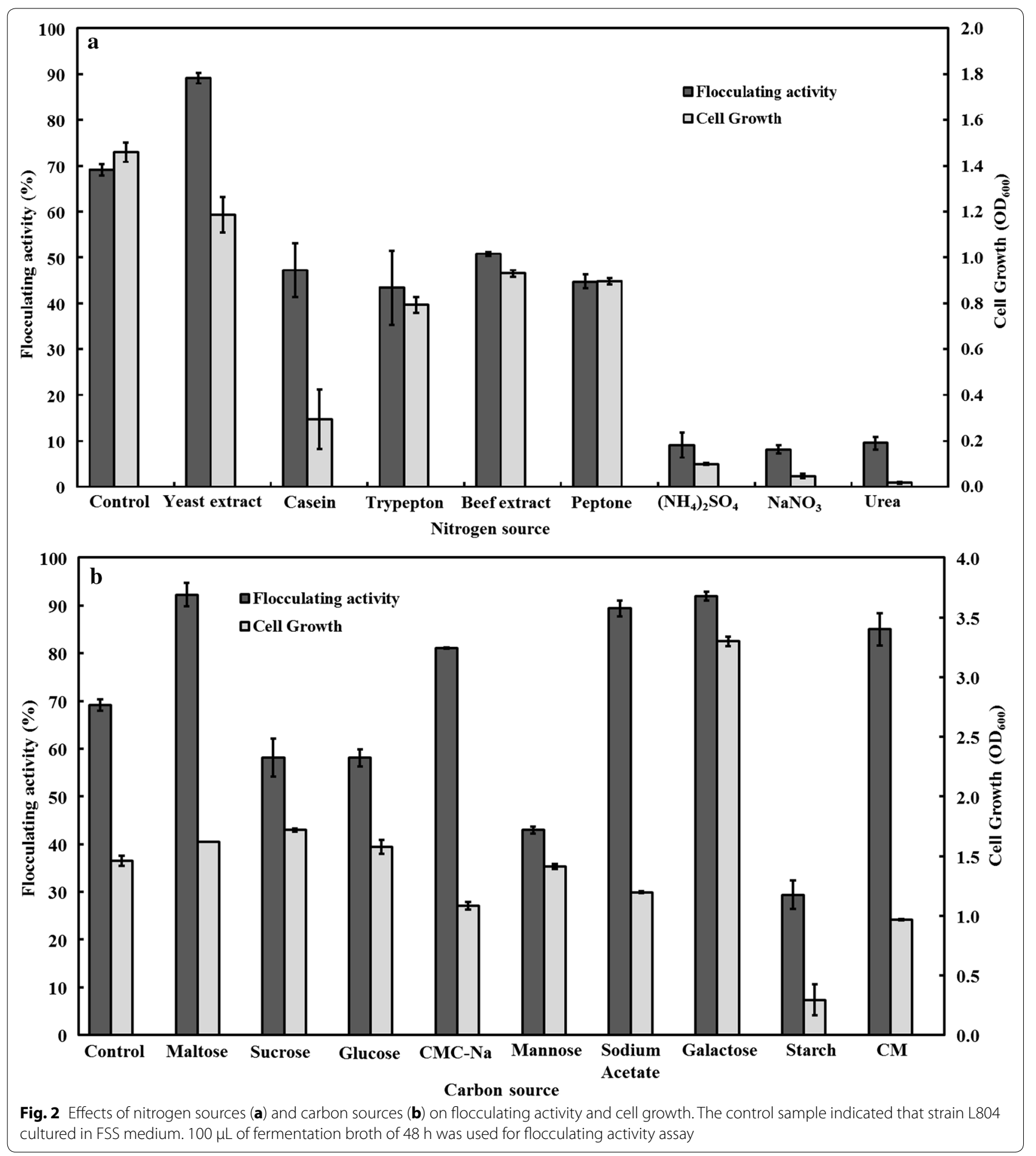

nitrogen source. As shown in Fig. 2b, flocculating activity over $80 \%$ was achieved when maltose, galactose, sodium acetate, carboxymethyl cellulose (CMC), and microcrystalline cellulose $(\mathrm{CM})$ were used as carbon sources. More exciting it was to find that strain L804 is able to produce bioflocculant using CMC and CM as carbon sources, confirming that strain L804 has the potential in conversion of lignocellulosic materials into bioflocculants. 


\section{Selection of lignocellulosic biomass to produce bioflocculant}

Seven kinds of lignocellulosic biomasses, including corn stover, corn cob, rice hull, potato residues, wheat bran, wheat straw, and peanut shell, were used as carbon sources of the fermentation medium. The results showed that over $80 \%$ flocculating activities were achieved when the corn stover, corn cob, potato residues, and peanut shell were used as carbon sources, which were much better than for rice hull, wheat bran, and wheat straw (data not shown). Then, the flocculating efficiencies of the broth-containing corn stover, corn cob, potato residues, and peanut shell were compared at different time intervals. As shown in Fig. 3, the flocculating activities of broth with four kinds of lignocellulosic biomasses were much higher than those of the control without added biomasses, and the highest flocculating activity was achieved when corn stover was used as carbon source. Flocculating efficiency over $90 \%$ was observed after the culture had been grown for $48 \mathrm{~h}$. Therefore, the corn stover was selected as optimal carbon source, and the highest titer of MBF-L804 achieved at the culture time of $48 \mathrm{~h}$ was $4.75 \mathrm{~g} / \mathrm{L}$, which is much higher than $0.13 \mathrm{~g} / \mathrm{L}$ of the control broth without added biomasses. After $48 \mathrm{~h}$ of culture, the titer decreased gradually with the increase of culture time. Therefore, the culture time of $48 \mathrm{~h}$ was selected to extract MBF-L804 in the following experiments. In addition, $1.2 \mathrm{~g} / \mathrm{L}$ soluble sugar was detected in the medium containing $20 \mathrm{~g} / \mathrm{L}$ corn stover before inoculating with strain L804. These soluble sugars can promote the initial growth of L804 cells and the secretion of lignocellulolytic enzymes, which further degrade the lignocellulosic biomasses. Soluble sugar of $1.2 \mathrm{~g} / \mathrm{L}$ was much lower than the titers of bioflocculant MBF-L804 $4.75 \mathrm{~g} / \mathrm{L}$, suggested that bioflocculant MBF-L804 was mainly produced from the degradation of lignocellulosic biomasses. The bioflocculant titer of $4.75 \mathrm{~g} / \mathrm{L}$ obtained in this study is much higher than the reported $2.4 \mathrm{~g} / \mathrm{L}$ bioflocculant secreted by Rhodococcus erythropolis in the medium using the hydrolyzates of rice stover as carbon source [44], but is lower than $6 \mathrm{~g} / \mathrm{L}$ bioflocculant produced by Ochrobactrum cicero W2 using the hydrolyzates of corn stover [53]. Although $O$. cicero W2 obtained a higher titer, the acidic hydrolysis of corn stover was under high-temperature and strong acidic conditions $\left(121{ }^{\circ} \mathrm{C}\right.$ and $1.7 \%$ sulfuric acid), and the acidic hydrolyzates required the neutralization of $\mathrm{pH}$ before the downstream fermentation processes, and the toxic by-products produced during the acidic hydrolysis process contaminated the bioflocculant product.

\section{Time curves of $\mathrm{pH}$, flocculating activity, cellulase, and xylanase}

The effects of $\mathrm{pH}$ on the activities of xylanase and cellulase present in the supernatant were determined. Figure $4 \mathrm{a}$ showed that the optimal $\mathrm{pH}$ for these two hydrolytic enzymes was around 5.2-6.0, which was

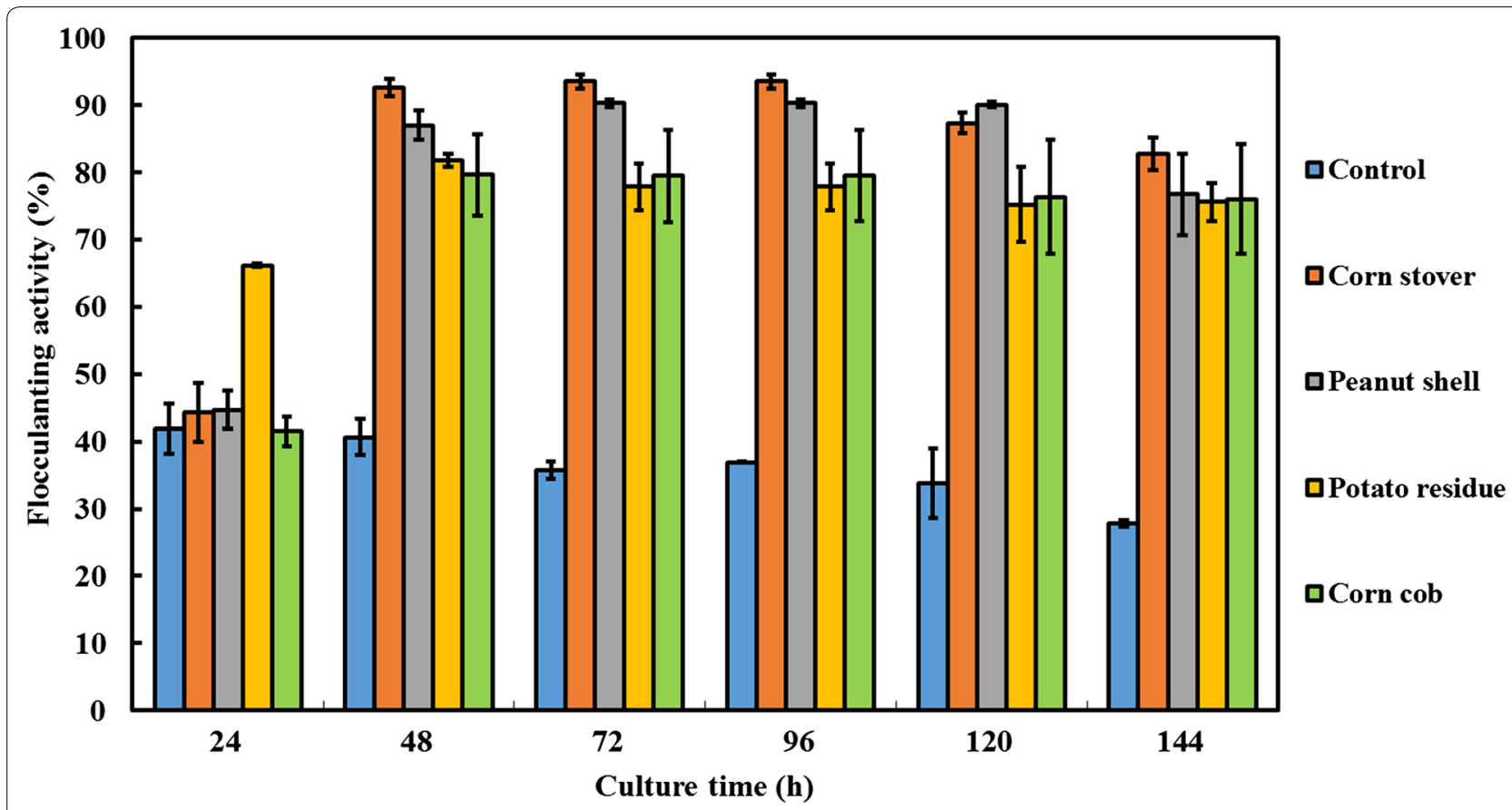

Fig. 3 Production of MBF-L804 using different lignocellulosic biomasses as carbon source. Strain L804 was cultured in the mediums (added with $3 \mathrm{~g} / \mathrm{L}$ yeast extract as nitrogen source and with different biomasses as carbon sources) and the control medium (added with $3 \mathrm{~g} / \mathrm{L}$ yeast extract, but without added biomasses). $100 \mu \mathrm{L}$ of fermentation broth of $48 \mathrm{~h}$ was taken for flocculating activity assay 

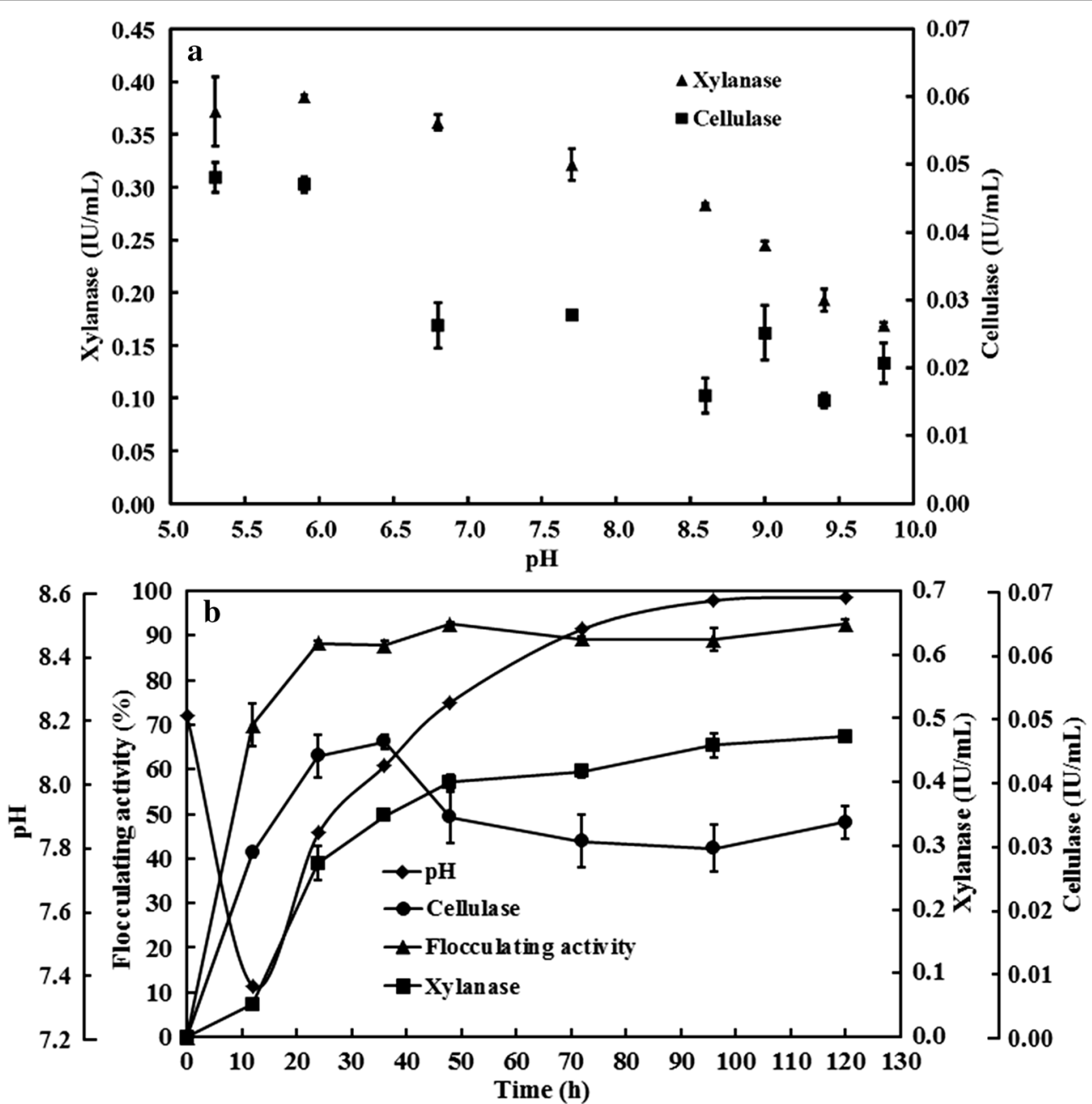

Fig. 4 Effects of pH on the activities of cellulase and xylanase produced by C. cellulans L804 (a) and variation curves of pH, flocculating activity, cellulase, and xylanase during cell growth in fermentation medium with corn stover as carbon source $(\mathbf{b})$. Error bars indicate standard deviation of at least three replicates

similar to a previous report [50]. Higher $\mathrm{pH}$ inhibited their activity. As mentioned above, the initial $\mathrm{pH} 8.2$ of fermentation medium was selected because the bioflocculant was not produced under acidic conditions. Although weak alkaline condition was not the optimal $\mathrm{pH}$ for xylanase and cellulase, more than $70 \%$ xylanase activity and $50 \%$ cellulase activity relative to their highest activities remained at the alkaline $\mathrm{pH}$.

The time profiles for $\mathrm{pH}$, flocculating activity of fermentation broth, cellulase, and xylanase were analyzed (Fig. $4 \mathrm{~b}$ ). The $\mathrm{pH}$ value decreased sharply from 8.2 to 7.4 in the first $12 \mathrm{~h}$. This decrease may be caused by the release of organic acids during the cell growth [50]. After 12-h culture, the $\mathrm{pH}$ increases may be due to the utilization of organic acids as carbon source. A similar change trend of $\mathrm{pH}$ was observed in a previous study [50]. Time profiles of cellulase and xylanase activities showed that enzymatic activities were not detectable at the beginning of the fermentation, suggesting that the enzyme content in the lignocellulosic biomass was negligible and that the enzymes were produced only by the microorganism. Figure $4 \mathrm{~b}$ shows sharp increases in the activities of two enzymes in the early stage of incubation: Xylanase was higher than cellulase. Over $0.6 \mathrm{IU} / \mathrm{mL}$ of xylanase activity was achieved after 24 -h culture. The highest cellulase activity of $0.046 \mathrm{IU} / \mathrm{mL}$ was achieved at $36 \mathrm{~h}$, which then decreased with time. No flocculating activity in fermentation broth was observed at the beginning, and the trends observed for enzyme activities were similar to that of the flocculating activity, suggesting that the conversion from corn stover into bioflocculant was dependent on the activity of hydrolytic enzymes produced by C. cellulans L804. 


\section{Characterization of the bioflocculant MBF-L804}

The components of MBF-L804 were determined. The results showed that the MBF-L804 contained $68.6 \%$ polysaccharides and $28.0 \%$ proteins. Polysaccharides were the major components of MBF-L804. Gel permeation chromatography analysis indicated that the approximate molecular weight (MW) of the purified bioflocculant L804 was $229 \mathrm{kDa}$. To reveal the functional groups involved in the flocculating activity of MBFL804, the FTIR spectrum of the MBF-L804 was analyzed (Additional file 1; Figure S1). The results showed that the MBF-L804 displayed a broad peak at around $3300 \mathrm{~cm}^{-1}$, indicating the presence of hydroxyl groups, and the spectrum also displayed a stretching band at $1680 \mathrm{~cm}^{-1}$ and a weak symmetric stretching band near $1420 \mathrm{~cm}^{-1}$, which are indicative of carboxyl groups. The absorption around $1080 \mathrm{~cm}^{-1}$ is known to be a characteristic for all sugar derivatives. The FTIR spectrum was consistent with the results of most bioflocculants produced by other organisms [28, 32, 54, 55].

\section{Flocculating properties of the bioflocculant MBF-L804}

The effects of temperature, metal ion, bioflocculant dosage, and $\mathrm{pH}$ on the flocculating activity were evaluated when the Kaolin clay was used as solid phase. The temperature is an important factor influencing the flocculating activity [23]. As shown in Fig. 5a, MBFL804 showed good heat stability. Over $85 \%$ flocculating activity was achieved at all the tested temperatures, and the highest flocculating activity of $92.68 \%$ was achieved at $35{ }^{\circ} \mathrm{C}$. This could be due to the main components of MBF-L804 being polysaccharides which are more heat stable compared with proteins or nucleic acids [22].

The effects of various metal ions on the flocculating acitivity of MBF-L804 were also investigated (Fig. 5b). It was found that the additions of $\mathrm{Ca}^{2+}$ and $\mathrm{Mg}^{2+}$ evidently enhanced the flocculating efficiency of MBF-L804. Metal ions are important in the process of flocculation [23]. The bioflocculant generated by Enterobacter aerogenes required the presence of $\mathrm{Zn}^{2+}$ [56]. The flocculating activity of bioflocculant secreted by Nannocystis sp. Nu-2 depended strongly on cations [57]. $\mathrm{Ca}^{2+}$ ion can enhance the flocculating efficiency of the bioflocculant produced by Bacillus agaradhaerens C9 [28]. Cations stimulate the flocculating activity by neutralizing and stabilizing the residual negative charge of functional groups and by forming the bridges between particles [54]. In this study, it was also found that MBF-L804 shows a good flocculating efficiency of $91.67 \%$ without adding any ion (Blank sample), and $\mathrm{Ca}^{2+}$ and $\mathrm{Mg}^{2+}$ can further improve the flocculating activity of MBF-L804.
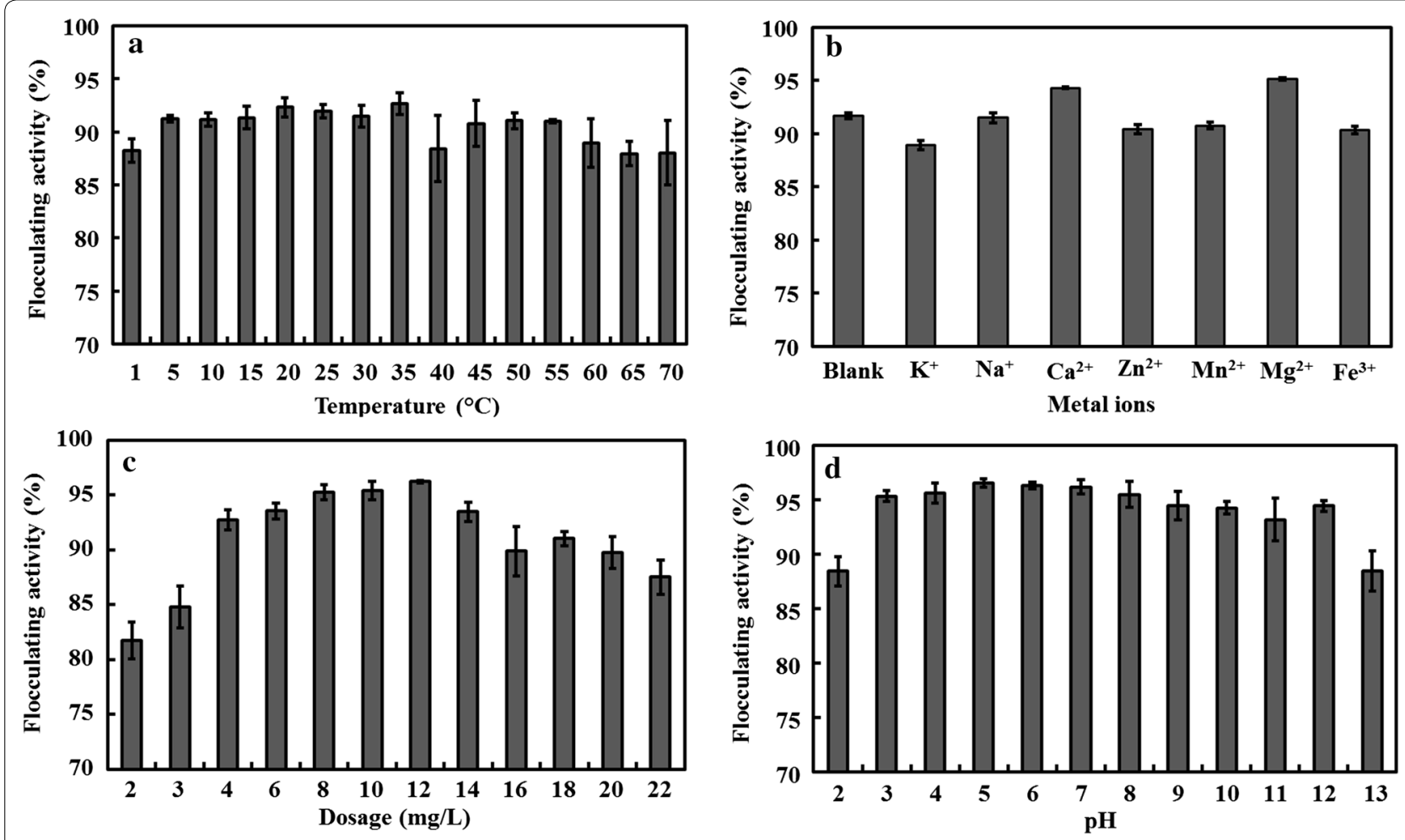

Fig. 5 Effects of temperature, metal ion, dosage, and pH on the flocculating activity of MBF-L804 
As shown in Fig. 5c, the flocculating activity over $90 \%$ was achieved in the concentration range of 4.0$14.0 \mathrm{mg} / \mathrm{L}$. The solution with lower or higher MBFL804 concentration showed poor flocculating activity. The bridging phenomenon between particles formed insufficiently when the MBF-L804 dosage was lower than $4 \mathrm{mg} / \mathrm{L}$. When the concentration was higher than $14.0 \mathrm{mg} / \mathrm{L}$, the decrease of flocculating activity could be explained by the repulsion between particles with the same negative charge due to the excessive introduction of charged polysaccharides. The similar relationship between bioflocculant concentration and flocculating activity was observed in other reported extracellular bioflocculants $[28,58]$. As shown in Fig. 5d, the flocculating activity of Kaolin suspension was over $90 \%$ in a wide $\mathrm{pH}$ range from 3 to 12 . The very wide $\mathrm{pH}$ and temperature ranges adaptable by MBF-L804 indicated the potential of using it in field applications.

\section{Application of MBF-L804 in harvesting two microalgae} Chlamydomonas reinhardtii and Chlorella minutissima are well known microalgae used for biodiesel production research $[59,60]$. Compared with traditional methods, such as centrifugation, filtration, and gravity sedimentation, flocculant is a low-cost option to harvest microalgae $[9,18,61]$. Therefore, the feasibility of flocculating $C$. reinhardtii and C. minutissima cells using MBF-L804 was investigated in this study. As shown in Fig. 6, the flocculating efficiencies of two microalgae enhanced with the increasing MBF-L804 concentration, and the flocculating efficiency $99.04 \%$ of $C$. reinhardtii was achieved when the culture supernatant of L804 was mixed with $C$. reinhardtii at a ratio of $1 / 3$. The flocculant of $C$. minutissima required more L804 culture supernatant, and flocculating efficiency of $93.83 \%$ was observed when the L804 supernatant was mixed with $C$. minutissima culture in a ratio $1 / 2$, which is significantly lower than the dosage used in previous studies. Wan et al. [3] reported that the bioflocculant produced by Solibacillus silvestris W01 can harvest 90 \% marine microalga Nannochloropsis oceanica DUT01 when the culture supernatant of W01 was mixed with the microalgal culture at a ratio of 3:1. Manheim and Nelson [27] reported that the bioflocculant secreted by Burkholderia cepacia could settle microalgae Scenedesmus sp. and Chlorella vulgaris when algae and bacteria suspensions were mixed in a $2: 1$ ratio $(v / v)$. In this study, strain L804 can produce bioflocculant by utilizing untreated lignocellulosic biomass as carbon source, which can avoid the capital expenditure intensive pretreatment step, and promote its application in harvesting of microalgae.

\section{Conclusions}

A novel bioflocculant-producing strain Cellulosimicrobium cellulans L804 which can secrete lignocellulolytic enzymes was isolated in this study. C. cellulans L804 can produce the bioflocculant MBF-L804 by degrading untreated lignocellulosic biomasses. The highest titer of $4.75 \mathrm{~g} / \mathrm{L}$ MBF-L804 was achieved under the optimal conditions: $20 \mathrm{~g} / \mathrm{L}$ dry corn stover as carbon source and $3 \mathrm{~g} / \mathrm{L}$

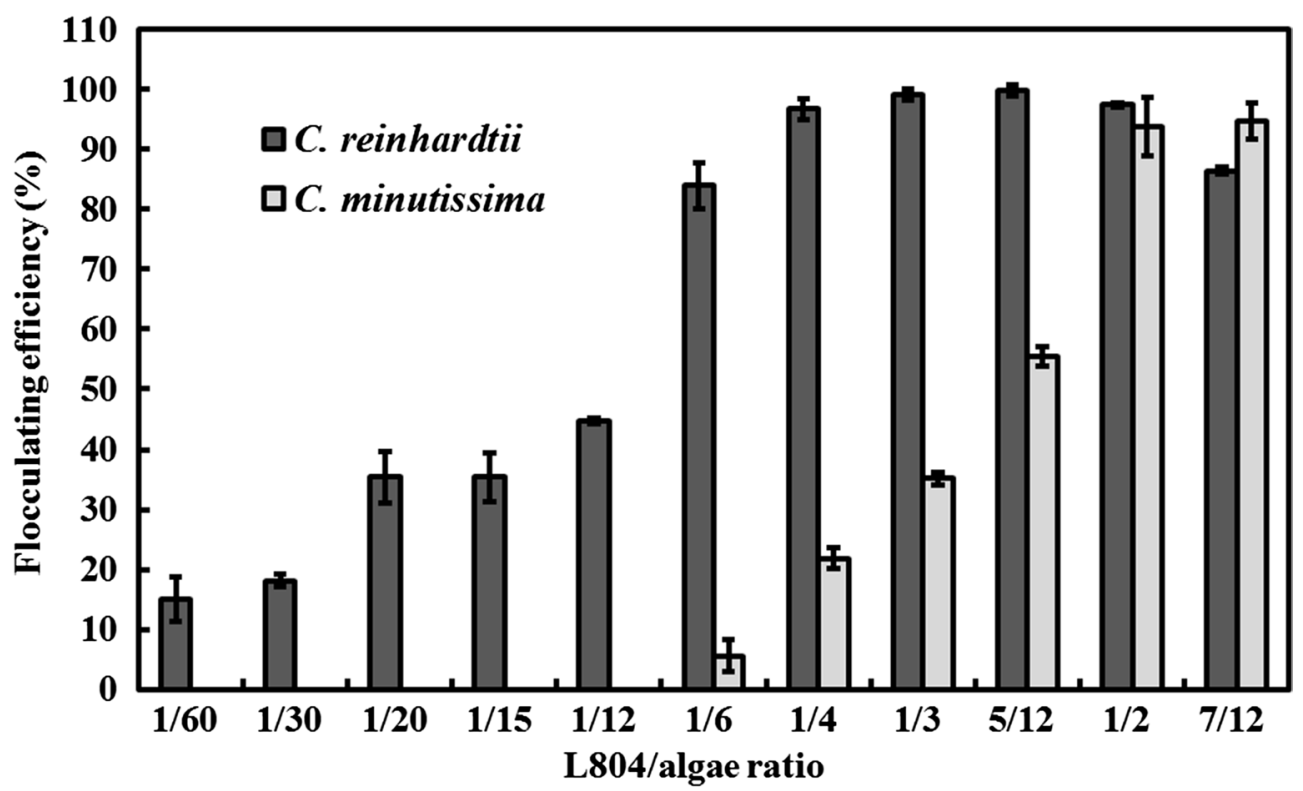

Fig. 6 Flocculating efficiencies of C. reinhardtii and C. minutissima in different volume ratios of L804 fermentation broth/microalgae culture 
yeast extract as nitrogen source. The MBF-L804 contained $68.6 \%$ polysaccharides and $28.0 \%$ proteins, and the approximate molecular weight (MW) of MBF-L804 was $229 \mathrm{kDa}$. In addition, MBF-L804 showed good flocculating efficiencies for $C$. reinhardtii and C. minutissima of 99.04 and $93.83 \%$, respectively.

\section{Methods}

Isolation of bioflocculant-producing strain

The soil samples were collected from the corn farmland to isolate functional strains which can produce both lignocellulolytic enzymes and bioflocculant. One gram of soil sample was suspended and serially diluted using $0.9 \%$ $\mathrm{NaCl}$ solution. The diluted solution was then loaded on the screening medium for isolating cellulase-producing strains and xylanase-producing strains when carboxymethyl cellulose (CMC) and xylan were used, respectively. The composition of the screening medium was as follows: $\mathrm{CMC}$ or oat spelt xylan $2 \mathrm{~g} / \mathrm{L}$, yeast extract $1 \mathrm{~g} / \mathrm{L}$, peptone $1 \mathrm{~g} / \mathrm{L}$, casein $1 \mathrm{~g} / \mathrm{L}, \mathrm{K}_{2} \mathrm{HPO}_{4} 1.2 \mathrm{~g} / \mathrm{L}, \mathrm{MgSO}_{4} \cdot 7 \mathrm{H}_{2} \mathrm{O}$ $0.2 \mathrm{~g} / \mathrm{L}$, with $\mathrm{pH}$ 7.2. After incubation at $37{ }^{\circ} \mathrm{C}$ for $48 \mathrm{~h}$, the plates were stained with $0.3 \%$ Congo red dye solution for $10 \mathrm{~min}$, followed by destaining with $1 \mathrm{M} \mathrm{NaCl}$ solution for $10 \mathrm{~min}$. The strains forming a clearing zone surrounding the colonies were purified and inoculated into 150-mL Erlenmeyer flasks containing $50 \mathrm{~mL}$ flocculating strain screening (FSS) medium (glucose $1 \mathrm{~g} / \mathrm{L}$, starch $1 \mathrm{~g} / \mathrm{L}$, yeast extract $1 \mathrm{~g} / \mathrm{L}$, peptone $1 \mathrm{~g} / \mathrm{L}$, casein $1 \mathrm{~g} / \mathrm{L}$, $\mathrm{K}_{2} \mathrm{HPO}_{4} 1.2 \mathrm{~g} / \mathrm{L}$, and $\mathrm{MgSO}_{4} \cdot 7 \mathrm{H}_{2} \mathrm{O} 0.2 \mathrm{~g} / \mathrm{L}$, with initial $\mathrm{pH}$ 7.2), and incubated in a shaker at $180 \mathrm{rpm}$ for $48 \mathrm{~h}$ at $37^{\circ} \mathrm{C}$. Then, the flocculating rate of each culture broth was determined. Strains with high flocculating activity were selected for further studies.

\section{Measurement of flocculating activity}

The flocculating activities of bioflocculant solution were measured by calculating the flocculating rate according to a previous study [28]. Briefly, Kaolin clay was used as the solid phase, and bioflocculant solution was added into a $5 \mathrm{~g} / \mathrm{L}$ Kaolin suspension and stirred for $2 \mathrm{~min}$. After settling for $1 \mathrm{~min}$, the absorbance $\left(\mathrm{OD}_{550}\right)$ of the supernatant sample was measured by a spectrophotometer (Unic-7200). A control experiment added with same volume of $\mathrm{H}_{2} \mathrm{O}$ was measured in the same manner. The flocculating rate was calculated according to the following equation: flocculating activity $=[\mathrm{A}-\mathrm{B}] / \mathrm{A} \times 100 \%$, where $B$ is the absorbance of the sample at $550 \mathrm{~nm}$, and $A$ is the absorbance of the control at $550 \mathrm{~nm}$.

\section{Identification of strain L804}

The 16S rRNA sequence was analyzed to identify the strain L804. The genomic DNA of L804 was extracted using Genomic DNA Mini Kit (Invitrogen). The 16S
rRNA gene fragment of the strain L804 was then amplified by PCR using forward primer (5'-GAG AGT TTG ATC CTG GCT CAG-3') and reverse primer (5'-CTA CGG CTA CCT TGT TAC GA-3'). The PCR product was purified using a PCR Purification Kit (Tiangen Biotech) and sequenced. The $16 \mathrm{~S}$ rRNA sequence of L804 was deposited into GenBank database (accession number: KT280277) and compared to the sequences available in the GenBank from the National Center for Biotechnology Information (NCBI) Database.

\section{Effects of initial $\mathrm{pH}$, nitrogen, and carbon sources on MBF-L804 production}

The initial $\mathrm{pH}$ of the medium was adjusted using $\mathrm{Na}_{2} \mathrm{CO}_{3}$ and $\mathrm{HCl}$ solution. The effects of $\mathrm{pH}$ variation in the range of 6.0-10.5 on cell growth and MBF-L804 production were evaluated. To analyze the effects of various nitrogen sources and carbon sources on cell growth and MBF-L804 production, the nitrogen sources of FSS medium was replaced by $3 \mathrm{~g} / \mathrm{L}$ different nitrogen sources, respectively, including yeast extract, casein, trypepton, beef extract, peptone, ammonium sulfate, sodium nitrate, and urea. The carbon sources was changed to $2 \mathrm{~g} / \mathrm{L}$ different carbon sources, respectively, including maltose, sucrose glucose, CMC-Na, mannose, sodium acetate, galactose, starch, $\mathrm{CM}$ when $3 \mathrm{~g} / \mathrm{L}$ yeast extract was used as nitrogen source.

\section{Selection of lignocellulosic biomass to produce bioflocculant}

To determine which lignocellulosic biomass is favorable for the bioflocculant production, corn stover, corn cob, rice hull, potato residues, wheat bran, wheat straw, and peanut shell, were obtained from Jiangsu province, and crushed into powders and sieved using a 40 mesh sieve. The bioflocculant titers and flocculating activities were compared when $20 \mathrm{~g} / \mathrm{L}$ of these different dry lignocellulosic biomasses were used as carbon source and $3 \mathrm{~g} / \mathrm{L}$ yeast extract was used as nitrogen source of the fermentation medium, and the medium (with $3 \mathrm{~g} / \mathrm{L}$ yeast extract, but without added biomasses) was used as a control to exclude the possibility that the bioflocculant was mainly produced from yeast extract.

\section{Production, and extraction of the bioflocculant}

C. cellulans L804 was grown in $50 \mathrm{~mL} 2 \times$ FSS medium $37^{\circ} \mathrm{C}$ overnight. Then, $1 \mathrm{~mL}$ seed culture was inoculated into $250-\mathrm{mL}$ flasks containing $100 \mathrm{~mL}$ fermentation medium and cultured at $37^{\circ} \mathrm{C}$ in a shaker with $200 \mathrm{rpm}$ shaking for $48 \mathrm{~h}$. The composition of the fermentation medium was as follows: untreated dry corn stover $20 \mathrm{~g} / \mathrm{L}$, yeast extract $3 \mathrm{~g} / \mathrm{L}, \mathrm{K}_{2} \mathrm{HPO}_{4} 1.2 \mathrm{~g} / \mathrm{L}, \quad \mathrm{MgSO}_{4} \cdot 7 \mathrm{H}_{2} \mathrm{O}$ $0.2 \mathrm{~g} / \mathrm{L}, \mathrm{Na}_{2} \mathrm{CO}_{3} 0.4 \mathrm{~g} / \mathrm{L}$, with initial $\mathrm{pH}$ 8.2. After 48-h incubation, the fermentation broth was centrifuged at 
$10,000 \mathrm{rpm}$ at $4{ }^{\circ} \mathrm{C}$ for $10 \mathrm{~min}$ to remove the cells and corn stover residues. The supernatant was collected for bioflocculant extraction. To extract the bioflocculant MBF-L804, two volumes of cold absolute ethanol were added into the broth to precipitate the bioflocculant. The resulting precipitate was collected by centrifugation at $10,000 \mathrm{rpm}, 4{ }^{\circ} \mathrm{C}$ for $5 \mathrm{~min}$, washed twice using $75 \%$ ethanol and lyophilized to obtain bioflocculant MBF-L804.

\section{Enzyme activity assay}

To determine the optimal $\mathrm{pH}$ for cellulase and xylanase, substrate were dissolved in $0.05 \mathrm{M}$ phosphate buffer $(\mathrm{pH}$ 5.2-7.7) and 0.05 $\mathrm{M}$ glycine- $\mathrm{NaOH}$ buffer ( $\mathrm{pH}$ 8.6-9.8).

The fermentation broth was collected at different time intervals and centrifuged at $8000 \mathrm{rpm}$, and the supernatant (enzyme solution) was used for cellulase and xylanase activity assay according to a previous study with slight modification [50]. Cellulase activity was analyzed using carboxymethyl cellulose $1 \%(\mathrm{w} / \mathrm{v})$ dissolved in $0.05 \mathrm{M}$ phosphate buffer ( $\mathrm{pH}$ 5.2) as a substrate. $50 \mu \mathrm{L}$ enzyme solution was mixed with $150 \mu \mathrm{L}$ of carboxymethyl cellulose solution. The resulting solution was incubated at $50{ }^{\circ} \mathrm{C}$ for $30 \mathrm{~min}$. The reaction was stopped by the addition of $100 \mu \mathrm{L} 1 \mathrm{M} \mathrm{NaOH}$ and $150 \mu \mathrm{L}$ dinitrosalicylic acid (DNS). $50 \mu \mathrm{L}$ enzyme solution cooked in boiling water for $5 \mathrm{~min}$ as control. Then, after adding $550 \mu \mathrm{L}$ $\mathrm{H}_{2} \mathrm{O}, \mathrm{OD}_{540}$ was measured using a spectrophotometer (Unic-7200). One enzyme activity unit was defined as the amount of enzyme that released $1 \mu \mathrm{M}$ of glucose per minute under the assayed conditions.

Xylanase activity was determined based on the amount of reducing sugars released from $0.5 \%(\mathrm{w} / \mathrm{v})$ xylan from oat spelts (Sigma). A $200 \mu \mathrm{L}$ reaction mixture, containing $50 \mu \mathrm{L}$ of enzyme solution and $150 \mu \mathrm{L}$ of a $0.5 \%(\mathrm{w} / \mathrm{v})$ suspension of xylan in $0.05 \mathrm{M}$ phosphate buffer ( $\mathrm{pH} 5.9)$, was incubated at $50{ }^{\circ} \mathrm{C}$ for $30 \mathrm{~min}$. The reducing sugars produced were assayed by the DNS method using xylose as standard. $50 \mu \mathrm{L}$ enzyme was cooked in boiling water for $5 \mathrm{~min}$ as control. The $\mathrm{OD}_{540}$ was measured using a spectrophotometer (Unic-7200). One enzyme unit was defined as the amount of enzyme that released $1 \mu \mathrm{M}$ of reducing sugar expressed as xylose equivalents $1 \mathrm{~min}$. All the above measurements were taken in triplicate, and enzyme activities were expressed in IU/mL of supernatant.

\section{Characteristics of bioflocculant MBF-L804}

The total polysaccharides of MBF-L804 were measured using the phenol-sulfuric acid method with glucose as the standard sample [62]. The total protein content was measured by the Bradford method with bovine serum albumin as the standard [63]. The molecular weight was determined by gel permeation chromatography (GPC) using a Hitachi L-6200 system controller [44]. Then, the bioflocculant MBF-L804 was analyzed using a Fourier transform infrared (FTIR) spectroscopy (Bruker Tensor 27, Germany). The spectrum of the sample in the $\mathrm{KBr}$ pellet was recorded on the spectrophotometer over a wave-number range of $600-4000 \mathrm{~cm}^{-1}$, and processed using the Bruker OPUS software.

\section{Flocculating properties of MBF-L804}

To get the knowledge of flocculating properties of MBFL804, the effects of temperature, metal ion, bioflocculant dosage, and $\mathrm{pH}$ on flocculating activity of Kaolin clay solutions were determined. The temperature of the Kaolin suspension was changed in the range of $1-70{ }^{\circ} \mathrm{C}$. To test the effect of metal ion on the flocculating activity, $1 \mathrm{~mL} 10 \mathrm{~g} / \mathrm{L} \mathrm{NaCl}, \mathrm{KCl}, \mathrm{CaCl}_{2}, \mathrm{ZnCl}_{2}, \mathrm{MnCl}_{2}, \mathrm{MgCl}_{2}$, $\mathrm{FeCl}_{3}$ solution was introduced into the $60 \mathrm{~mL}$ flocculating system. The bioflocculant dosage was varied from 2 to $22 \mathrm{mg} \mathrm{L}^{-1}$. The $\mathrm{pH}$ of the Kaolin suspension was adjusted using $\mathrm{HCl}$ and $\mathrm{NaOH}$ in the $\mathrm{pH}$ range of 2.1-12.9.

\section{Culture of two microalgae and its harvest by bioflocculant MBF-L804}

Chlorella minutissima was cultured in 500-mL Erlenmeyer flask containing $200 \mathrm{~mL}$ IM medium [64] which is composed of glucose $17.5 \mathrm{~g} / \mathrm{L}$, casein $13 \mathrm{~g} / \mathrm{L}$, yeast extract $0.1 \mathrm{~g} / \mathrm{L}, \mathrm{NH}_{4} \mathrm{Cl} 2 \mathrm{~g} / \mathrm{L}, \mathrm{KH}_{2} \mathrm{PO}_{4} 1 \mathrm{~g} / \mathrm{L}, \mathrm{Na}_{2} \mathrm{HPO}_{4}$ $2 \mathrm{~g} / \mathrm{L}, \mathrm{MgSO}_{4} \cdot 7 \mathrm{H}_{2} \mathrm{O} 0.5 \mathrm{~g} / \mathrm{L}, \mathrm{FeSO}_{4} \cdot 7 \mathrm{H}_{2} \mathrm{O} 0.01 \mathrm{~g} / \mathrm{L}, \mathrm{CaCl}_{2}$ $0.01 \mathrm{~g} / \mathrm{L}, \quad \mathrm{Al}_{2}\left(\mathrm{SO}_{4}\right)_{3} \cdot 18 \mathrm{H}_{2} \mathrm{O} 3.58 \mathrm{mg} / \mathrm{L}, \quad \mathrm{MnCl}_{2} \cdot 4 \mathrm{H}_{2} \mathrm{O}$ $12.98 \mathrm{mg} / \mathrm{L}, \quad \mathrm{CuSO}_{4} \cdot 5 \mathrm{H}_{2} \mathrm{O} 1.83 \mathrm{mg} / \mathrm{L}, \quad \mathrm{ZnSO}_{4} \cdot 7 \mathrm{H}_{2} \mathrm{O}$ $3.2 \mathrm{mg} / \mathrm{L}, \mathrm{pH}$ 7.0. Chlamydomonas reinhardtii was grown in liquid TAP medium, which is composed of TAP salts $\left(\mathrm{NH}_{4} \mathrm{Cl} 15 \mathrm{~g} / \mathrm{L}, \mathrm{MgSO}_{4} \cdot 7 \mathrm{H}_{2} \mathrm{O} 4 \mathrm{~g} / \mathrm{L}, \mathrm{CaCl}_{2} \cdot 2 \mathrm{H}_{2} \mathrm{O} 2 \mathrm{~g} / \mathrm{L}\right)$ $25 \mathrm{~mL} / \mathrm{L}$, Phosphate solution $\left(\mathrm{K}_{2} \mathrm{HPO}_{4} 288 \mathrm{~g} / \mathrm{L}, \mathrm{KH}_{2} \mathrm{PO}_{4}\right.$ $144 \mathrm{~g} / \mathrm{L}$ ) $0.375 \mathrm{~mL} / \mathrm{L}$, Hutner's trace elements (EDTA disodium salt $50 \mathrm{~g} / \mathrm{L}, \mathrm{ZnSO}_{4} \cdot 7 \mathrm{H}_{2} \mathrm{O} 22 \mathrm{~g} / \mathrm{L}, \mathrm{H}_{3} \mathrm{BO}_{3} 11.4 \mathrm{~g} / \mathrm{L}$, $\mathrm{MnCl}_{2} \cdot 4 \mathrm{H}_{2} \mathrm{O} 5.06 \mathrm{~g} / \mathrm{L}, \mathrm{CoCl} \cdot 6 \mathrm{H}_{2} \mathrm{O} 1.61 \mathrm{~g} / \mathrm{L}, \mathrm{CuSO}_{4} \cdot 5 \mathrm{H}_{2} \mathrm{O}$ $1.57 \mathrm{~g} / \mathrm{L}, \quad\left(\mathrm{NH}_{4}\right)_{6} \mathrm{Mo}_{7} \mathrm{O}_{24} \cdot 4 \mathrm{H}_{2} \mathrm{O} 1.1 \mathrm{~g} / \mathrm{L}, \quad \mathrm{FeSO}_{4} \cdot 7 \mathrm{H}_{2} \mathrm{O}$ $4.99 \mathrm{~g} / \mathrm{L}, \mathrm{pH} 7.0) 1 \mathrm{~mL} / \mathrm{L}$, Glacial acetic acid $1 \mathrm{~mL} / \mathrm{L}$, and Tris $2.42 \mathrm{~g} / \mathrm{L}$. Both two microalgae were cultivated at $23{ }^{\circ} \mathrm{C}$ for a $14 / 10$-h light/dark cycle for 1 week. L804 fermentation broth of different volumes was added into $60 \mathrm{~mL}$ microalgae culture, and mixed with $0.8 \mathrm{~mL} 10 \%$ $\mathrm{CaCl}_{2}$. After stirring for $5 \mathrm{~min}$ and settling for $10 \mathrm{~min}$, the supernatant was removed carefully. Then, the flocculated-microalgae were collected. All the microalgal cells of $60 \mathrm{~mL}$ culture were collected by centrifuged at 10,000 rpm 5 min directly as a control. After washing twice with $\mathrm{H}_{2} \mathrm{O}$, the microalgal samples were lyophilized. The flocculating efficiency was calculated according to the following equation: flocculating efficiency $=\mathrm{A} / \mathrm{B} \times 100 \%$, where $\mathrm{A}$ is the dry weight of the flocculated sample, and B is the dry weight of the control sample. 


\section{Additional file}

Additional file 1: Figure S1. Fourier transform infrared spectroscopy of bioflocculant MBF-L804.

\section{Abbreviations}

MBF: microbial flocculant; CMC: carboxymethyl cellulose; CM: microcrystalline cellulose; PCR: polymerase chain reaction; DNS: 3, 5-dinitrosalicylic acid; NCBI: National Center for Biotechnology Information; GPC: Gel permeation chromatography; FSS: flocculating strain screening medium; FTIR: Fourier transform infrared spectroscopy.

\section{Authors' contributions}

WL carried out the identification of bioflocculant-producing strains, participated in characteristic analysis of bioflocculant, and drafted the manuscript. CZ carried out the isolation of bioflocculant-producing strains and drafted the manuscript. JJ participated in the design of the study, performed the statistical analysis and helped to revise the manuscript. QL participated in the analysis of enzyme activity and drafted the manuscript. YH carried out the preparation and the characteristic analysis of bioflocculant and drafted the manuscript. LW carried out the culture of microalgae and helped to revise the manuscript. $\mathrm{CL}$ carried out the culture and the harvest of microalgae and drafted the manuscript. All authors participated in drafting the work or revising it critically for important intellectual content. All authors have read and approved the final manuscript.

\section{Acknowledgements}

We are grateful to Jinshui Yang for the gift of Chlorella minutissima. This research was supported by the National Natural Science Foundation of China (31300054; 31370646), the Youth Fund of the Natural Science Foundation of Jiangsu Province of China (BK20130228), the Grants from the Natural Science Foundation by Xuzhou Normal University (13XLR032), and the Priority Academic Program Development of Jiangsu Higher Education Institutions (PAPD).

\section{Competing interests}

The authors declare that they have no competing interests.

Received: 2 August 2015 Accepted: 5 October 2015

Published online: 20 October 2015

\section{References}

1. Olguín EJ. Dual purpose microalgae-bacteria-based systems that treat wastewater and produce biodiesel and chemical products within a Biorefinery. Biotechnol Adv. 2012;30(5):1031-46.

2. Brennan L, Owende P. Biofuels from microalgae-a review of technologies for production, processing, and extractions of biofuels and co-products. Renew Sust Energ Rev. 2010;14(2):557-77.

3. Wan C, Zhao XQ, Guo SL, Alam MA, Bai FW. Bioflocculant production from Solibacillus silvestris W01 and its application in cost-effective harvest of marine microalga Nannochloropsis oceanica by flocculation. Bioresourc Technol. 2013;135:207-12.

4. Rumin J, Bonnefond H, Saint-Jean B, Rouxel C, Sciandra A, Bernard O, Gadoret JP, Bougaran G. The use of fluorescent Nile red and BODIPY for lipid measurement in microalgae. Biotechnol Biofuels. 2015;8(1):42.

5. Ogawa T, Tamoi M, Kimura A, Mine A, Sakuyama H, Yoshida E, Maruta T, Suzuki K, Ishikawa T, Shigeoka S. Enhancement of photosynthetic capacity in Euglena gracilis by expression of cyanobacterial fructose-1,6-/ sedoheptulose-1,7-bisphosphatase leads to increases in biomass and wax ester production. Biotechnol Biofuels. 2015;8(1):80

6. Muradov N, Taha M, Miranda AF, Wrede D, Kadali K, Gujar A, Stevenson T, Ball AS, Mouradov A. Fungal-assisted algal flocculation: application in wastewater treatment and biofuel production. Biotechnol Biofuels. 2015;8(24):1-23.
7. Kim DG, La HJ, Ahn CY, Park YH, Oh HM. of Scenedesmus sp. with bioflocculant and reuse of culture medium for subsequent high-density cultures. Bioresourc Technol. 2011;102(3):3163-8.

8. Lee AK, Lewis DM, Ashman PJ. Microbial flocculation, a potentially lowcost harvesting technique for marine microalgae for the production of biodiesel. J Appl Phycol. 2009;21(5):559-67.

9. Leite GB, Abdelaziz AE, Hallenbeck PC. Algal biofuels: challenges and opportunities. Bioresourc Technol. 2013;145:134-41.

10. Garg S, Wang L, Schenk PM. Effective harvesting of low surfacehydrophobicity microalgae by froth flotation. Bioresourc Technol. 2014;159:437-41.

11. Pragya N, Pandey KK, Sahoo P. A review on harvesting, oil extraction and biofuels production technologies from microalgae. Renew Sust Energ Rev. 2013:24:159-71.

12. Coward T, Lee JG, Caldwell GS. Development of a foam flotation system for harvesting microalgae biomass. Algal Res. 2013;2(2):135-44.

13. Grima EM, Belarbi EH, Fernández FA, Medina AR, Chisti Y. Recovery of microalgal biomass and metabolites: process options and economics. Biotechnol Adv. 2003;20(7):491-515.

14. Che R, Huang L, Yu X. Enhanced biomass production, lipid yield and sedimentation efficiency by iron ion. Bioresourc Technol. 2015;192:795-8.

15. Barros Al, Gonçalves AL, Simões M, Pires JC. Harvesting techniques applied to microalgae: A review. Renew Sust Energ Rev. 2015:41:1489-500.

16. Oh HM, Lee SJ, Park MH, Kim HS, Kim HC, Yoon JH, Kwon GS, Yoon BD. Harvesting of Chlorella vulgaris using a bioflocculant from Paenibacillus sp. AM49. Biotechnol Lett. 2001;23(15):1229-34.

17. Banerjee C, Ghosh S, Sen G, Mishra S, Shukla P, Bandopadhyay R. Study of algal biomass harvesting using cationic guar gum from the natural plant source as flocculant. Carbohydr Polym. 2013;92(1):675-81.

18. Vandamme D, Foubert I, Muylaert K. Flocculation as a low-cost method for harvesting microalgae for bulk biomass production. Trends Biotechnol. 2013:31(4):233-9.

19. Christenson L, Sims R. Production and harvesting of microalgae for wastewater treatment, biofuels, and bioproducts. Biotechnol Adv. 2011;29(6):686-702

20. Zhou W, Cheng Y, Li Y, Wan Y, Liu Y, Lin X, Ruan R. Novel fungal pelletization-assisted technology for algae harvesting and wastewater treatment. Appl Biochem Biotechnol. 2012;167(2):214-28.

21. Xie S, Sun S, Dai SY, Yuan JS. Efficient coagulation of microalgae in cultures with filamentous fungi. Algal Res. 2013;2(1):28-33

22. Salehizadeh $\mathrm{H}$, Shojaosadati S. Extracellular biopolymeric flocculants: recent trends and biotechnological importance. Biotechnol Adv. 2001;19(5):371-85.

23. Salehizadeh $H$, Yan N. Recent advances in extracellular biopolymer flocculants. Biotechnol Adv. 2014;32(8):1506-22.

24. Xia S, Zhang Z, Wang X, Yang A, Chen L, Zhao J, Leonard D, JaffrezicRenault N. Production and characterization of a bioflocculant by Proteus mirabilis TJ-1. Bioresourc Technol. 2008;99(14):6520-7.

25. Liu W, Liu C, Yuan H, Yang J. The mechanism of kaolin clay flocculation by a cation-independent bioflocculant produced by Chryseobacterium daeguense W6. AIMS Environ Sci. 2015;2(2):169-79.

26. Salehizadeh $\mathrm{H}$, Vossoughi M, Alemzadeh I. Some investigations on bioflocculant producing bacteria. Biochem Eng J. 2000;5(1):39-44.

27. Manheim D, Nelson Y. Settling and bioflocculation of two species of algae used in wastewater treatment and algae biomass production. Environ Prog Sustain Energ. 2013;32(4):946-54.

28. Liu C, Wang K, Jiang JH, Liu WJ, Wang JY. A novel bioflocculant produced by a salt-tolerant, alkaliphilic and biofilm-forming strain Bacillus agaradhaerens $\mathrm{C} 9$ and its application in harvesting Chlorella minutissima UTEX2341. Biochem Eng J. 2015;93:166-72.

29. Wang L, Ma F, Lee DJ, Wang A, Ren N. Bioflocculants from hydrolysates of corn stover using isolated strain Ochrobactium ciceri W2. Bioresourc Technol. 2013;145:259-63.

30. He N, Li Y, Chen J, Lun SY. Identification of a novel bioflocculant from a newly isolated Corynebacterium glutamicum. Biochem Eng J. 2002;11(2):137-48.

31. Wang SG, Gong WX, Liu XW, Tian L, Yue QY, Gao BY. Production of a novel bioflocculant by culture of Klebsiella mobilis using dairy wastewater. Biochem Eng J. 2007;36(2):81-6. 
32. Liu W, Wang K, Li B, Yuan H, Yang J. Production and characterization of an intracellular bioflocculant by Chryseobacterium daeguense W6 cultured in low nutrition medium. Bioresourc Technol. 2010;101(3):1044-8.

33. More T, Yan S, Hoang N, Tyagi R, Surampalli R. Bacterial polymer production using pre-treated sludge as raw material and its flocculation and dewatering potential. Bioresourc Technol. 2012;121:425-31.

34. Guo J, Yang C, Zeng G. Treatment of swine wastewater using chemically modified zeolite and bioflocculant from activated sludge. Bioresourc Technol. 2013;143:289-97.

35. Peng L, Yang C, Zeng G, Wang L, Dai C, Long Z, Liu H, Zhong Y. Characterization and application of bioflocculant prepared by Rhodococcus erythropolis using sludge and livestock wastewater as cheap culture media. Appl Microbiol Biotechnol. 2014;98(15):6847-58.

36. Bezawada J, Hoang N, More T, Yan S, Tyagi N, Tyagi R, Surampalli RY. Production of extracellular polymeric substances (EPS) by Serratia sp. 1 using wastewater sludge as raw material and flocculation activity of the EPS produced. J Environ Manage. 2013;128:83-91.

37. Guo J, Zhang Y, Zhao J, Zhang Y, Xiao X, Wang B, Shu B. Characterization of a bioflocculant from potato starch wastewater and its application in sludge dewatering. Appl Microbiol Biotechnol. 2015;99:5429-37.

38. Guo J, Lau AK, Zhang Y, Zhao J. Characterization and flocculation mechanism of a bioflocculant from potato starch wastewater. Appl Microbiol Biotechnol. 2015;99:5855-61.

39. Pu SY, Qin LL, Che JP, Zhang BR, Xu M. Preparation and application of a novel bioflocculant by two strains of Rhizopus sp. using potato starch wastewater as nutrilite. Bioresourc Technol. 2014;162:184-91.

40. Wong YS, Ong SA, Teng TT, Aminah LN, Kumaran K. Production of bioflocculant by Staphylococcus cohnii ssp. from palm oil mill effluent (POME). Water Air Soil Poll. 2012;223(7):3775-81.

41. Aljuboori AHR, Uemura Y, Osman NB, Yusup S. Production of a bioflocculant from Aspergillus niger using palm oil mill effluent as carbon source. Bioresourc Technol. 2014;171:66-70.

42. Zhong C, Xu A, Chen L, Yang X, Yang B, Hong W, Mao K, Wang B, Zhou J. Production of a bioflocculant from chromotropic acid waste water and its application in steroid estrogen removal. Colloids Surf B Biointerfaces. 2014; 122:729-37.

43. Zhang ZQ, Bo L, Xia SQ, Wang XJ, Yang AM. Production and application of a novel bioflocculant by multiple-microorganism consortia using brewery wastewater as carbon source. J Environ Sci. 2007;19(6):667-73.

44. Guo J, Yu J, Xin X, Zou C, Cheng Q, Yang H, Nengzi L. Characterization and flocculation mechanism of a bioflocculant from hydrolyzate of rice stover. Bioresourc Technol. 2015;177:393-7.

45. Sun Y, Cheng J. Hydrolysis of lignocellulosic materials for ethanol production: a review. Bioresourc Technol. 2002;83(1):1-11.

46. Mussatto SI, Roberto IC. Alternatives for detoxification of diluted-acid lignocellulosic hydrolyzates for use in fermentative processes: a review. Bioresourc Technol. 2004;93(1):1-10.

47. Palmqvist E, Hahn-Hägerdal B. Fermentation of lignocellulosic hydrolysates. I: inhibition and detoxification. Bioresourc Technol. 2000;74(1):17-24

48. Zhang J, Zhu Z, Wang X, Wang N, Wang W, Bao J. Biodetoxification of toxins generated from lignocellulose pretreatment using a newly isolated fungus, Amorphotheca resinae ZN 1, and the consequent ethanol fermentation. Biotechnol Biofuels. 2010;3(1):26.
49. Ferrer P. Revisiting the Cellulosimicrobium cellulans yeast-lytic $\beta-1,3-$ glucanases toolbox: a review. Microb Cell Fact. 2006;5(1):10

50. Song JM, Wei DZ. Production and characterization of cellulases and xylanases of Cellulosimicrobium cellulans grown in pretreated and extracted bagasse and minimal nutrient medium M9. Biomass Bioenergy. 2010;34(12):1930-4.

51. Lo YC, Saratale GD, Chen WM, Bai MD, Chang JS. Isolation of cellulosehydrolytic bacteria and applications of the cellulolytic enzymes for cellulosic biohydrogen production. Enzyme Microb Technol. 2009;44(6):417-25.

52. Thomsen MH, Thygesen A, Thomsen AB. Identification and characterization of fermentation inhibitors formed during hydrothermal treatment and following SSF of wheat straw. Appl Microbiol Biotechnol. 2009;83(3):447-55.

53. Wang L, Lee DJ, Ma F, Wang A, Ren N. Bioflocculants from isolated strain or mixed culture: Role of phosphate salts and $\mathrm{Ca}^{2+}$ ions. J Taiwan Inst Chem Eng. 2014;45(2):527-32.

54. Yim JH, Kim SJ, Ahn SH, Lee HK. Characterization of a novel bioflocculant, $\mathrm{p}-\mathrm{KG03}$, from a marine dinoflagellate, Gyrodinium impudicum KG03. Bioresourc Technol. 2007;98(2):361-7.

55. Zhao H, Liu H, Zhou J. Characterization of a bioflocculant MBF-5 by Klebsiella pneumoniae and its application in Acanthamoeba cysts removal. Bioresourc Technol. 2013;137:226-32.

56. Lu WY, Zhang T, Zhang DY, Li CH, Wen JP, Du LX. A novel bioflocculant produced by Enterobacter aerogenes and its use in defecating the trona suspension. Biochem Eng J. 2005;27(1):1-7.

57. Zhang J, Liu Z, Wang S, Jiang P. Characterization of a bioflocculant produced by the marine myxobacterium Nannocystis sp. NU-2. Appl Microbiol Biotechnol. 2002;59(4-5):517-22.

58. Zheng Y, Ye ZL, Fang XL, Li YH, Cai WM. Production and characteristics of a bioflocculant produced by Bacillus sp. F19. Bioresourc Technol. 2008;99(16):7686-91.

59. Wang H, Alvarez S, Hicks LM. Comprehensive comparison of iTRAQ and label-free LC-based quantitative proteomics approaches using two Chlamydomonas reinhardtii strains of interest for biofuels engineering. J Proteome Res. 2011;11(1):487-501.

60. Yang J, Rasa E, Tantayotai P, Scow KM, Yuan H, Hristova KR. Mathematical model of Chlorella minutissima UTEX2341 growth and lipid production under photoheterotrophic fermentation conditions. Bioresourc Technol. 2011;102(3):3077-82.

61. González-Fernández C, Ballesteros M. Microalgae autoflocculation: an alternative to high-energy consuming harvesting methods. J Appl Phycol. 2013;25(4):991-9.

62. Chaplin MF, Kennedy JF. Carbohydrate analysis: a practical approach. Ed. 2. IRL Press Ltd. 1994.

63. Bradford MM. A rapid and sensitive method for the quantitation of microgram quantities of protein utilizing the principle of protein-dye binding. Anal Biochem. 1976;72(1):248-54.

64. Cao J, Yuan H, Li B, Yang J. Significance evaluation of the effects of environmental factors on the lipid accumulation of Chlorella minutissima UTEX 2341 under low-nutrition heterotrophic condition. Bioresourc Technol. 2014;152:177-84

\section{Submit your next manuscript to BioMed Central and take full advantage of:}

- Convenient online submission

- Thorough peer review

- No space constraints or color figure charges

- Immediate publication on acceptance

- Inclusion in PubMed, CAS, Scopus and Google Scholar

- Research which is freely available for redistribution

Submit your manuscript at

www.biomedcentral.com/submit
C Biomed Central 